\title{
Comparison of Standard Light Water Reactor Cross-Section Libraries using the United States Nuclear Regulatory Commission Pressurized Water Reactor Standard Core Loading Benchmark Problem
}

\author{
F. Arzu Alpan ${ }^{\mathrm{a}}$ and Joel A. Kulesza \\ Westinghouse Electric Company, 1000 Westinghouse Drive, Suite 332, Cranberry Township, \\ PA 16066, USA
}

\begin{abstract}
This paper compares contemporary and historical light water reactor shielding and pressure vessel dosimetry cross-section libraries for a pressurized water reactor calculational benchmark problem with a standard out-in core loading. The calculational benchmark problem was developed at Brookhaven National Laboratory by the request of the U. S. Nuclear Regulatory Commission and used the Oak Ridge National Laboratory two-dimensional discrete ordinates code DORT and the BUGLE-93 cross-section library for the calculations. In this paper, a Westinghouse three-dimensional discrete ordinates code with parallel processing, the RAPTOR-M3G code was used. A variety of cross section libraries were used with RAPTOR-M3G including the BUGLE-93, BUGLE-96, and BUGLE-B7 cross-section libraries developed at Oak Ridge National Laboratory, and the broad-group ALPAN-VII.0 cross-section library developed at Westinghouse. In comparing the calculation-to-calculation reaction rates using the BUGLE-93 cross-section library at the thermal shield, pressure vessel, and cavity capsules, for eleven dosimetry reaction rates, a maximum relative difference of $5 \%$ was observed, with the exception of ${ }^{65} \mathrm{Cu}(\mathrm{n}, 2 \mathrm{n})$ in the pressure vessel capsule that had a $90 \%$ relative difference with respect to the reference results. It is thought that the ${ }^{65} \mathrm{Cu}(\mathrm{n}, 2 \mathrm{n})$ reaction rate reported in the reference for the pressure vessel capsule is not correct. In considering the libraries developed after BUGLE93, a maximum relative difference of $12 \%$ was observed in reaction rates, with respect to the reference results, for ${ }^{237} \mathrm{~Np}(\mathrm{n}, \mathrm{f})$ in the cavity capsule using BUGLE-B7.
\end{abstract}

\section{Introduction}

This paper documents radiation transport calculation results using the Westinghouse-developed RApid Parallel Transport Of Radiation - Multiple 3-D Geometries (RAPTOR-M3G) code version 2.0 [1] with Oak Ridge National Laboratory-developed Broad User Group Library ENDF/B-93 (BUGLE-93) [2], BUGLE-96 [3], BUGLE-B7 [4], and A Library for Photons And Neutrons with ENDF/B-VII.0 (ALPAN-VII.0) [5], for the U. S. Nuclear Regulatory Commission (USNRC) pressurized water reactor (PWR) pressure vessel fluence calculational benchmark problem [6].

The RAPTOR-M3G code is a Westinghouse-developed three-dimensional (3-D) radiation transport code that solves the linear Boltzmann transport equation in $\mathrm{x}-\mathrm{y}-\mathrm{z}$ or $\mathrm{r}-\theta-\mathrm{z}$ geometry using the method

\footnotetext{
${ }^{a}$ Corresponding author: alpanfa@westinghouse.com
} 


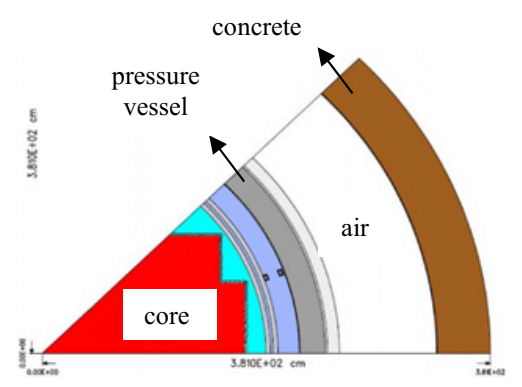

Figure 1. PWR r- $\theta$ geometry at core midplane.

of discrete ordinates $\left(\mathrm{S}_{\mathrm{N}}\right.$ method) via parallel processing. The parallel processing capability of RAPTOR-M3G was implemented using Message Passing Interface (MPI) libraries. The BUGLE-93 and BUGLE-96 libraries were developed at Oak Ridge National Laboratory (ORNL) and contain a coupled 47-neutron, 20-gamma-ray group cross-section library for light water reactor shielding and pressure vessel dosimetry applications derived from ENDF/B-VI.2 and ENDF/B-VI.3 [7], respectively. The BUGLE-B7 library, the latest of the BUGLE libraries, has the same group structure of BUGLE93 and BUGLE-96, and uses ENDF/B-VII.0. ALPAN-VII.0 was developed at Westinghouse for PWR internals and pressure vessel dosimetry applications, based on ENDF/B-VII.0 [8] and using the contributon and point-wise cross section driven methodology [9]. ALPAN-VII.0 contains crosssection sets with coupled 461-neutron, 42-gamma-ray-group and coupled 44-neutron, 20-gamma-ray group structures. The 42- and 20-gamma-ray group structures were taken from VITAMIN-B6 [3] and BUGLE-96, respectively. Therefore, only the neutron group structure of ALPAN-VII.0 was developed at Westinghouse. In this project, only ALPAN-VII.0 in a broad-group structure (coupled 44-neutron, 20-gamma-ray-group) was used.

The USNRC PWR vessel fluence benchmark problems are for a typical 204 fuel assembly PWR core including the core baffle and barrel, thermal shield, and a vessel having an inner radius of $\sim 219.1 \mathrm{~cm}$. The thermal power is $2527.73 \mathrm{MWt}$ with an average coolant temperature of $293.3^{\circ} \mathrm{C}$. The active fuel length is $335.28 \mathrm{~cm}$. Benchmark problems are defined for three types of fuel loadings:

1. Standard out-in core loading (SCL),

2. Low-leakage core loading (LLCL), and

3. Core including partial length shield assemblies (PLSAs).

Reference 6 provides results of the USNRC benchmark problems calculated using the ORNL twodimensional (2-D) discrete ordinates code DORT version 2.8.14 to perform a 2-D/one-dimensional (1-D) flux synthesis and using the BUGLE-93 cross-section library. MCNP Monte Carlo calculations were also performed for the PWR SCL and PLSA core loading to validate the flux synthesis results. For this work, only the SCL PWR benchmark calculations were pursued. Note that the geometric description of the three benchmark cases listed above is the same; therefore, the geometry developed in this work can be used for the LLCL and PLSA core loading benchmarks in the future.

\section{Geometry Modelling}

The BOT3P code [10] was used for modelling an r- $\theta$-z octant of the SCL PWR based on the geometry specifications provided in Reference 6 . The $\mathrm{r}-\theta$ of an octant and $\mathrm{r}-\mathrm{z}$ views of the $3-\mathrm{D}$ reactor model are shown in Figs. 1 and 2, respectively. 


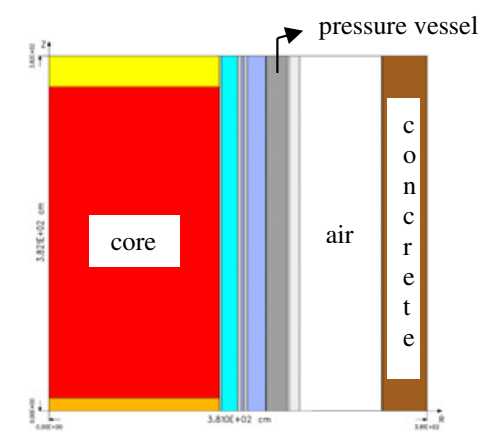

Figure 2. PWR r-z geometry at $\theta=0^{\circ}$.

The models shown in Figs. 1 and 2 have 177 radial, 100 azimuthal, and 127 axial meshes. As indicated in Figs. 1 and 2, the geometry extends radially, azimuthally, and axially, up to $381 \mathrm{~cm}$, an octant (i.e., $45^{\circ}$ ), and $381 \mathrm{~cm}$, respectively.

\section{Source Distribution}

A Westinghouse-developed source generation code was used to produce an $\mathrm{r}-\theta$-z source distribution for an octant of the SCL PWR. The assembly power distributions were based on a $15 \times 15$ fuel assembly pinwise power distribution. Only the peripheral fuel assembly power distributions were modelled explicitly. The assemblies were modelled with an assembly pitch of $21.485 \mathrm{~cm}$.

Pin-by-pin distributions of the peripheral assemblies input to the Westinghouse-developed source generation code were obtained from data on a CD distributed with Reference 6 . The pin powers provided in the $\mathrm{CD}$ were normalized such that one-eighth of the total core power equalled to 1.0. The pin-by-pin distributions for each assembly were re-normalized to average 1.0 over all pin locations.

The relative fuel assembly powers for the peripheral assemblies and the axial power distribution were obtained from Reference 6. The initial fuel assembly enrichments were not provided in Reference 6; however an approximate enrichment of $2 \mathrm{w} / \mathrm{o}{ }^{235} \mathrm{U}$ was used for all assemblies. This approximation was based on running a set of cases in the Westinghouse-developed source generation code with assembly enrichments ranging from 1.5 w/o to 4.6 w/o with 1 w/o increments and examining the output of the cases for nuclide-dependent fission fractions of ${ }^{235} \mathrm{U},{ }^{238} \mathrm{U},{ }^{239} \mathrm{Pu},{ }^{240} \mathrm{Pu},{ }^{241} \mathrm{Pu}$, and ${ }^{242} \mathrm{Pu}$ as a function of burnup, including 1.5E $+2,5.0 \mathrm{E}+2,1.0 \mathrm{E}+4,2.0 \mathrm{E}+4$, and 4.0E $+4 \mathrm{MWD}$. Reference 6 provides fraction of fission by isotope $\left({ }^{235} \mathrm{U},{ }^{238} \mathrm{U},{ }^{239} \mathrm{Pu},{ }^{240} \mathrm{Pu},{ }^{241} \mathrm{Pu}\right.$, and $\left.{ }^{242} \mathrm{Pu}\right)$ at $1.5 \mathrm{E}+2,5.0 \mathrm{E}+2$, $1.0 \mathrm{E}+4,2.0 \mathrm{E}+4$, and 4.0E $+4 \mathrm{MWD}$. Comparing fraction of fission by isotope as a function of exposure documented in Reference 6 and those calculated by the Westinghouse-developed source generation code, using a $2 \% \mathrm{w} / \mathrm{o}{ }^{235} \mathrm{U}$ enrichment for all assembles was found to be reasonable assumption. Fission fractions of $9.3909 \mathrm{E}-01$ and $6.085 \mathrm{E}-02$ were used for ${ }^{235} \mathrm{U}$ and ${ }^{238} \mathrm{U}$, respectively, for all of the data libraries.

For the BUGLE-93, BUGLE-96 and BUGLE-B7 group structures, the fission spectrum by isotope ${ }^{235} \mathrm{U},{ }^{238} \mathrm{U},{ }^{239} \mathrm{Pu},{ }^{240} \mathrm{Pu},{ }^{241} \mathrm{Pu}$, and $\left.{ }^{242} \mathrm{Pu}\right)$ given in Reference 6 was used. For the 44-neutron group structure, the fission spectrum was calculated using NJOY 99.259 and ENDF/B-VII.0. A gamma source was not modelled.

\section{Material Cross Sections}

Atom densities of each component in the PWR materials are given in Reference 6. The ICE code [11] was used to generate mixture cross sections for BUGLE-93, BUGLE-96, BUGLE-B7, and 
Table 1. Dosimetry Energy Response Ranges.

\begin{tabular}{|c|c|c|}
\hline Dosimetry Reaction & \multirow{2}{*}{\multicolumn{2}{|c|}{ Energy Response Range (MeV) }} \\
\hline${ }^{65} \mathrm{Cu}(\mathrm{n}, 2 \mathrm{n}){ }^{64} \mathrm{Cu}$ & & $\mathrm{E}>10.5^{*}$ \\
\hline Dosimetry Reaction & Low $\mathbf{E}_{05} * *$ & High $\mathbf{E}_{95} * *$ \\
\hline${ }^{63} \mathrm{Cu}(\mathrm{n}, \alpha){ }^{60} \mathrm{Co}$ & 4.53 & 11.0 \\
\hline${ }^{54} \mathrm{Fe}(\mathrm{n}, \mathrm{p}){ }^{54} \mathrm{Mn}$ & 5.45 & 11.3 \\
\hline${ }^{58} \mathrm{Ni}(\mathrm{n}, \mathrm{p}){ }^{58} \mathrm{Co}$ & 1.98 & 7.51 \\
\hline${ }^{238} \mathrm{U}(\mathrm{n}, \mathrm{f}){ }^{137} \mathrm{Cs}$ & 1.44 & 6.69 \\
\hline${ }^{237} \mathrm{~Np}(\mathrm{n}, \mathrm{f}){ }^{137} \mathrm{Cs}$ & 0.684 & 5.61 \\
\hline${ }^{27} \mathrm{Al}(\mathrm{n}, \alpha){ }^{24} \mathrm{Na}$ & 6.45 & 11.9 \\
\hline${ }^{32} \mathrm{~S}(\mathrm{n}, \mathrm{p}){ }^{32} \mathrm{P}$ & 2.28 & 7.33 \\
\hline${ }^{56} \mathrm{Fe}(\mathrm{n}, \mathrm{p})^{56} \mathrm{Mn}$ & 5.45 & 11.3 \\
\hline${ }^{46} \mathrm{Ti}(\mathrm{n}, \mathrm{p}){ }^{46} \mathrm{Sc}$ & 1.70 & 6.76 \\
\hline${ }^{115} \operatorname{In}\left(\mathrm{n}, \mathrm{n}^{\prime}\right)^{115 \mathrm{~m}} \operatorname{In}$ & 1.12 & 5.86 \\
\hline
\end{tabular}

ALPAN-VII.0 in broad-group structure. Mixture cross sections included downscattering cross sections only, with an upscattering removal treatment in thermal energies.

\section{Dosimetry Cross Sections}

For the transport calculations using BUGLE-93, BUGLE-96, and BUGLE-B7, 47-neutron-group dosimetry cross sections provided in Reference 6 for ${ }^{27} \mathrm{Al}(\mathrm{n}, \alpha),{ }^{32} \mathrm{~S}(\mathrm{n}, \mathrm{p}),{ }^{46} \mathrm{Ti}(\mathrm{n}, \mathrm{p}),{ }^{54} \mathrm{Fe}(\mathrm{n}, \mathrm{p}),{ }^{56} \mathrm{Fe}(\mathrm{n}, \mathrm{p})$, ${ }^{58} \mathrm{Ni}(\mathrm{n}, \mathrm{p}),{ }^{63} \mathrm{Cu}(\mathrm{n}, \alpha),{ }^{65} \mathrm{Cu}(\mathrm{n}, 2 \mathrm{n}),{ }^{115} \mathrm{In}\left(\mathrm{n}, \mathrm{n}^{\prime}\right),{ }^{237} \mathrm{~Np}(\mathrm{n}, \mathrm{f})$, and ${ }^{238} \mathrm{U}(\mathrm{n}, \mathrm{f})$ were used. For the ALPANVII.0 broad-group transport calculations, 44-neutron-group dosimetry cross sections were calculated by processing ENDF/B-VI.2 data (for consistency with Reference 6) with NJOY in 461-neutron groups (the fine-group ALPAN-VII.0 group structure) and using AMPX modules for further processing. For the 461-neutron-group to 44-neutron group collapsing, the flux spectrum at a location corresponding to the quarter thickness inside the pressure vessel was used, which was obtained from a 3-loop PWR model. The dosimetry energy response ranges of the reactions of interest are provided in Table 1.

\section{Transport Calculations}

The three-dimensional RAPTOR-M3G code was used to perform transport calculations with an $\mathrm{S}_{8}$ quadrature and $\mathrm{P}_{3}$ scattering cross sections using BUGLE-93, BUGLE-96, BUGLE-B7, and ALPANVII.0 cross-section libraries for the calculational benchmark defined in Reference 6 . A flux convergence criterion of $10^{-3}$ was used for inner iterations. Results of the transport calculations were compared with Reference 6 that used the ORNL discrete ordinates code DORT in 2-D r- $\theta$ and r-z geometry and 1-D r geometry for a 2-D/1-D flux synthesis, which performed transport calculations with an $\mathrm{S}_{8}$ quadrature and $\mathrm{P}_{3}$ scattering cross sections, and used the BUGLE-93 cross section library, and also used a flux convergence criterion of $10^{-3}$ for inner iterations. Calculations were analyzed at capsule locations given in Table 2. Figure 3 shows the flux per unit lethargy as a function of energy using Reference 6 and BUGLE-93 results. Figures 4, 5, and 6 show flux per unit lethargy as a function of energy calculated for the capsule locations on the outer wall of the thermal shield, on the inner wall of the pressure vessel, and in the cavity, respectively. Note that there are differences in neutron fluxes calculated by the four libraries, particularly in the thermal energy range $(\mathrm{E}<5 \mathrm{eV})$. When BUGLE-93 was developed, upscattering in the thermal energy range was not considered; upscattering was introduced in BUGLE-96 as an improvement to BUGLE-93. While upscattering was considered in the newer libraries, 
Table 2. Capsule locations.

\begin{tabular}{|c|c|c|c|c|}
\hline Region & Radius $(\mathbf{c m})$ & Axial Location $(\mathbf{c m})^{(\mathbf{1})}$ & Azimuthal Angle (Degrees) $^{\text {Location }}$ \\
\hline Thermal shield & 202.25 & 121.79 & 20 & $\begin{array}{c}\text { Outer wall of } \\
\text { thermal shield }\end{array}$ \\
\hline Pressure vessel & 215.43 & 121.79 & 20 & $\begin{array}{c}\text { Inner wall of } \\
\text { pressure vessel }\end{array}$ \\
\hline Cavity & 320.06 & 177.27 & 9.5 & Inside cavity \\
\hline \multicolumn{2}{|l|}{ Core midplane is at $181.61 \mathrm{~cm}}$. \\
\hline
\end{tabular}

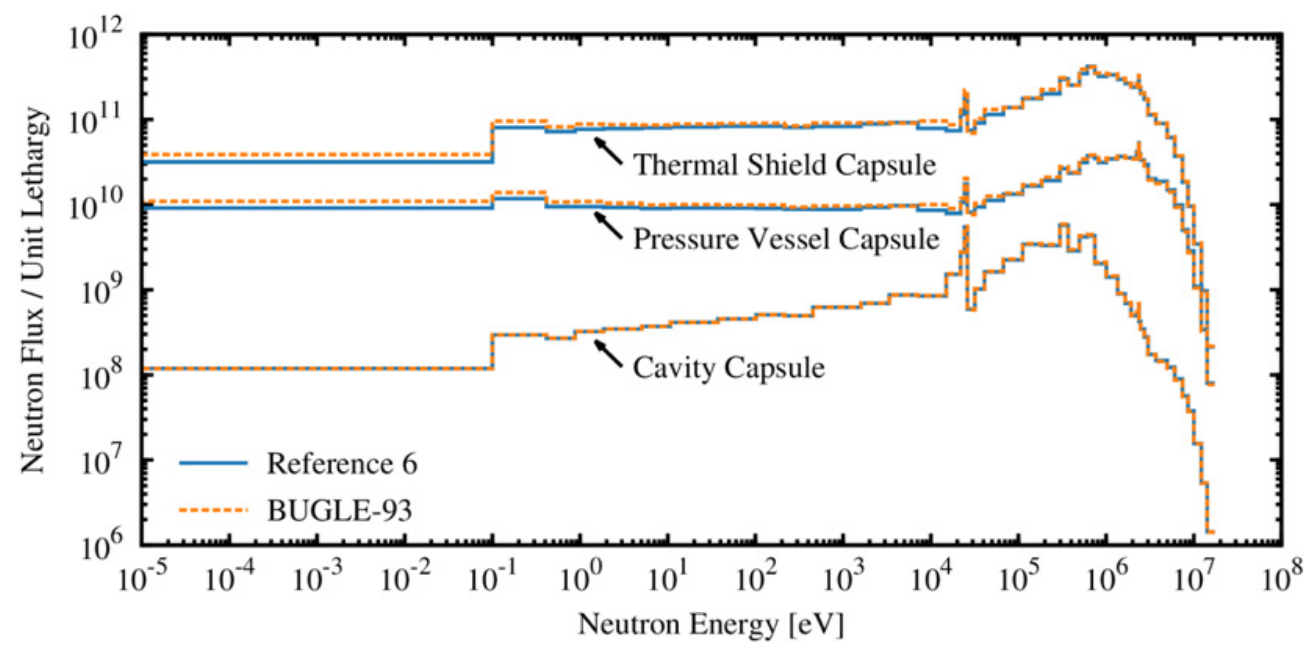

Figure 3. Flux spectrum in the thermal shield, pressure vessel, and cavity capsules for Reference 6 and BUGLE-93.

Table 3. Flux and percent relative difference in flux with respect to Reference 6 at the thermal shield capsule.

\begin{tabular}{|c|c|c|c|c|c|}
\hline Parameter & Reference 6 & BUGLE-93 & BUGLE-96 & BUGLE-B7 & ALPAN-VII.0 \\
\hline $\begin{array}{c}\text { Flux }\left(\mathrm{n} / \mathrm{cm}^{2}-\mathrm{s}\right) \\
\mathrm{E}>1.0 \mathrm{MeV}\end{array}$ & $3.74 \mathrm{E}+11$ & $3.80 \mathrm{E}+11(2 \%)^{*}$ & $3.80 \mathrm{E}+11(2 \%)^{*}$ & $3.78 \mathrm{E}+11(1 \%)^{*}$ & $3.75 \mathrm{E}+11(<1 \%)^{*}$ \\
\hline $\begin{array}{c}\text { Flux }\left(\mathrm{n} / \mathrm{cm}^{2}-\mathrm{s}\right) \\
\mathrm{E}>0.1 \mathrm{MeV}\end{array}$ & $9.66 \mathrm{E}+11$ & $1.00 \mathrm{E}+12(4 \%)^{*}$ & $9.99 \mathrm{E}+11(3 \%)^{*}$ & $9.88 \mathrm{E}+11(2 \%)^{*}$ & $9.71 \mathrm{E}+11(<1 \%)^{*}$ \\
\hline
\end{tabular}

* Percent relative difference with respect to Reference 6.

i.e., BUGLE-96, BUGLE-B7, and ALPAN-VII.0, the upscattering treatment used in BUGLE-96 and ALPAN-VII.0 differ, which is observed as differences in the thermal energy range. ALPAN-VII.0 uses the ANISN method of upscattering treatment. While the BUGLE-96 manual specifies that the ANISN method of upscattering treatment is used in BUGLE-96, investigation has shown that this is not the case. Regarding BUGLE-B7, a detailed investigation on the upscattering treatment will be performed, but according to comparisons between BUGLE-B7 and BUGLE-B7T, it is thought that BUGLE-B7 also does not incorporate the ANISN method of upscattering treatment. Tables 3, 4, and 5 give neutron fluxes for $\mathrm{E}>1.0 \mathrm{MeV}$ and $\mathrm{E}>0.1 \mathrm{MeV}$ and comparisons with Reference 6 .

Tables 6, 7, and 8 give calculated reaction rates and comparisons of results with Reference 6 for the thermal shield, pressure vessel, and cavity capsules, respectively. Excluding ${ }^{65} \mathrm{Cu}(\mathrm{n}, 2 \mathrm{n})$ in the pressure vessel capsule, the maximum relative difference with respect to Reference 6 results, considering all four libraries, is $12 \%$ for ${ }^{237} \mathrm{~Np}(\mathrm{n}, \mathrm{f})$ using BUGLE-B7. The differences in the ${ }^{237} \mathrm{~Np}(\mathrm{n}$,f) reaction rates between BUGLE-93 and the newer libraries is expected to occur due to the different iron energy 


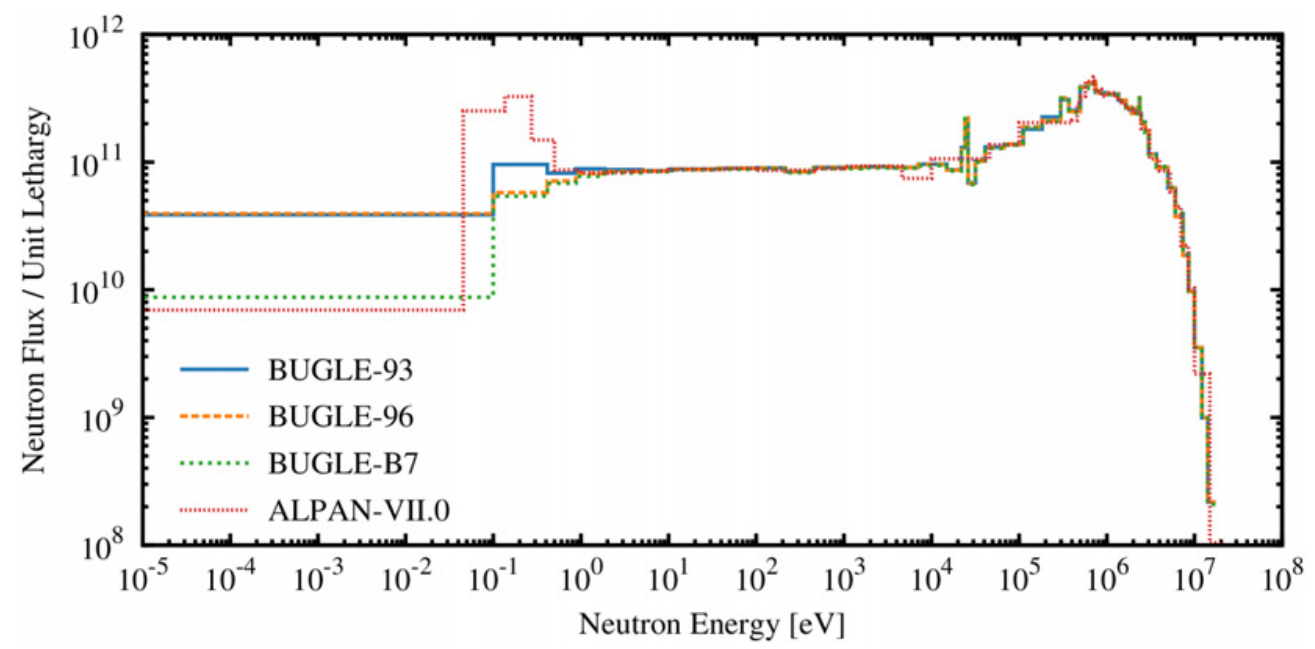

Figure 4. Flux spectrum on the outer wall of the thermal shield for BUGLE-93, BUGLE-96, BUGLE-B7 and ALPAN-VII.0.

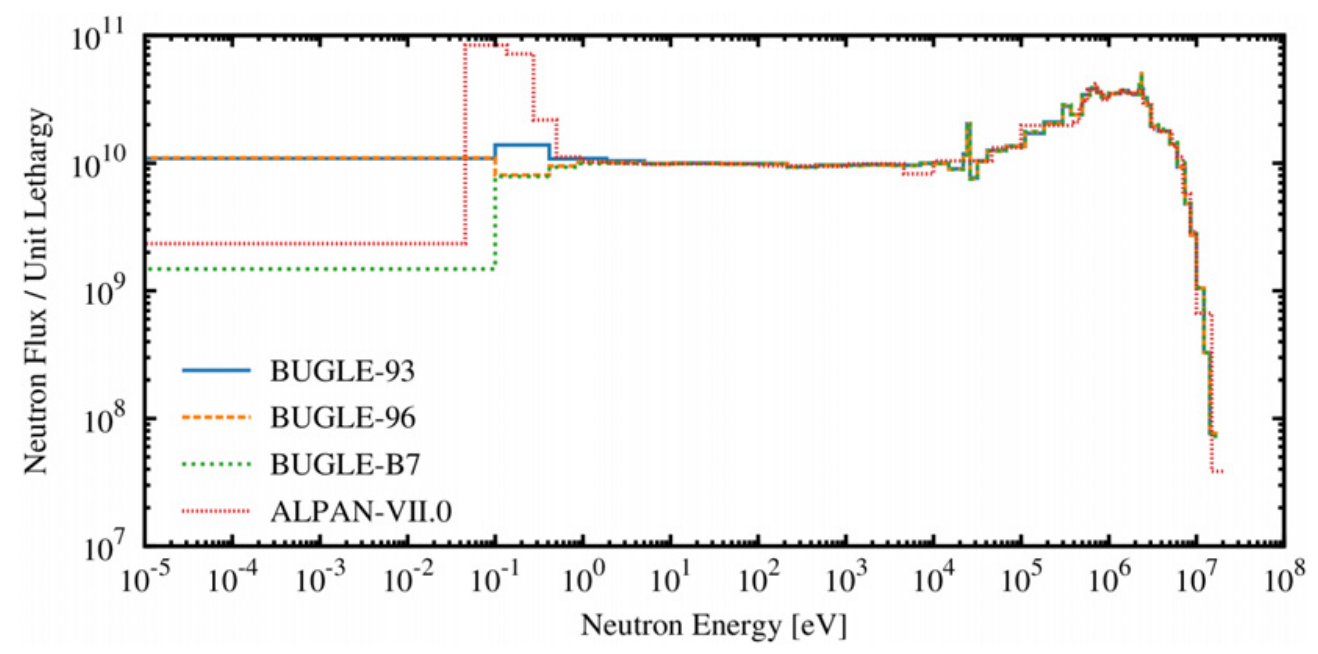

Figure 5. Flux spectrum on the inner wall of the pressure vessel for BUGLE-93, BUGLE-96, BUGLE-B7, and ALPAN-VII.0

Table 4. Flux and percent relative difference in flux with respect to Reference 6 at the pressure vessel capsule.

\begin{tabular}{|c|c|c|c|c|c|}
\hline Parameter & Reference 6 & BUGLE-93 & BUGLE-96 & BUGLE-B7 & ALPAN-VII.0 \\
\hline $\begin{array}{c}\text { Flux }\left(\mathrm{n} / \mathrm{cm}^{2}-\mathrm{s}\right) \\
\mathrm{E}>1.0 \mathrm{MeV}\end{array}$ & $5.50 \mathrm{E}+10$ & $5.39 \mathrm{E}+10(-2 \%)^{*}$ & $5.39 \mathrm{E}+10(-2 \%)^{*}$ & $5.48 \mathrm{E}+10(<1 \%)^{*}$ & $5.39 \mathrm{E}+10(-2 \%)^{*}$ \\
\hline $\begin{array}{c}\text { Flux }\left(\mathrm{n} / \mathrm{cm}^{2}-\mathrm{s}\right) \\
\mathrm{E}>0.1 \mathrm{MeV}\end{array}$ & $1.10 \mathrm{E}+11$ & $1.12 \mathrm{E}+11(2 \%)^{*}$ & $1.12 \mathrm{E}+11(1 \%)^{*}$ & $1.13 \mathrm{E}+11(3 \%)^{*}$ & $1.11 \mathrm{E}+11(1 \%)^{*}$ \\
\hline
\end{tabular}

* Percent relative difference with respect to Reference 6. 


\section{$15^{\text {th }}$ ISRD}

Table 5. Flux and percent relative difference in flux with respect to Reference 6 at the cavity capsule.

\begin{tabular}{|c|c|c|c|c|c|}
\hline Parameter & Reference 6 & BUGLE-93 & BUGLE-96 & BUGLE-B7 & ALPAN-VII.0 \\
\hline $\begin{array}{c}\text { Flux }\left(\mathrm{n} / \mathrm{cm}^{2}-\mathrm{s}\right) \\
\mathrm{E}>1.0 \mathrm{MeV}\end{array}$ & $1.04 \mathrm{E}+09$ & $1.05 \mathrm{E}+09(1 \%)^{*}$ & $1.09 \mathrm{E}+09(6 \%)^{*}$ & $1.11 \mathrm{E}+09(8 \%)^{*}$ & $1.07 \mathrm{E}+09(3 \%)^{*}$ \\
\hline $\begin{array}{c}\text { Flux }\left(\mathrm{n} / \mathrm{cm}^{2}-\mathrm{s}\right) \\
\mathrm{E}>0.1 \mathrm{MeV}\end{array}$ & $8.99 \mathrm{E}+09$ & $9.21 \mathrm{E}+09(2 \%)^{*}$ & $1.00 \mathrm{E}+10(12 \%)^{*}$ & $1.02 \mathrm{E}+10(14 \%)^{*}$ & $9.94 \mathrm{E}+09(11 \%)^{*}$ \\
\hline
\end{tabular}

* Percent relative difference with respect to Reference 6.

Table 6. Percent relative difference in reaction rates with respect to Reference 6 at the thermal shield capsule.

\begin{tabular}{|c|c|c|c|c|}
\hline Dosimetry Isotope & BUGLE-93 (\%) & BUGLE-96 (\%) & BUGLE-B7 (\%) & ALPAN-VII.0 (\%) \\
\hline${ }^{27} \mathrm{Al}(\mathrm{n}, \alpha)$ & $2 \%$ & $2 \%$ & $4 \%$ & $5 \%$ \\
\hline${ }^{32} \mathrm{~S}(\mathrm{n}, \mathrm{p})$ & $1 \%$ & $1 \%$ & $2 \%$ & $3 \%$ \\
\hline${ }^{46} \mathrm{Ti}(\mathrm{n}, \mathrm{p})$ & $1 \%$ & $1 \%$ & $4 \%$ & $3 \%$ \\
\hline${ }^{54} \mathrm{Fe}(\mathrm{n}, \mathrm{p})$ & $1 \%$ & $1 \%$ & $3 \%$ & $2 \%$ \\
\hline${ }^{56} \mathrm{Fe}(\mathrm{n}, \mathrm{p})$ & $1 \%$ & $1 \%$ & $5 \%$ & $5 \%$ \\
\hline${ }^{58} \mathrm{Ni}(\mathrm{n}, \mathrm{p})$ & $1 \%$ & $1 \%$ & $2 \%$ & $1 \%$ \\
\hline${ }^{63} \mathrm{Cu}(\mathrm{n}, \alpha)$ & $1 \%$ & $1 \%$ & $5 \%$ & $4 \%$ \\
\hline${ }^{65} \mathrm{Cu}(\mathrm{n}, 2 \mathrm{n})$ & $2 \%$ & $2 \%$ & $2 \%$ & $11 \%$ \\
\hline${ }^{115} \mathrm{In}\left(\mathrm{n}, \mathrm{n}^{\prime}\right)$ & $2 \%$ & $2 \%$ & $1 \%$ & $0 \%$ \\
\hline${ }^{237} \mathrm{~Np}(\mathrm{n}, \mathrm{f})$ & $3 \%$ & $3 \%$ & $1 \%$ & $2 \%$ \\
\hline${ }^{238} \mathrm{U}(\mathrm{n}, \mathrm{f})$ & $1 \%$ & $1 \%$ & $1 \%$ & $0 \%$ \\
\hline
\end{tabular}

Table 7. Percent relative difference in reaction rates with respect to Reference 6 at the pressure vessel capsule.

\begin{tabular}{|c|c|c|c|c|}
\hline Dosimetry Isotope & BUGLE-93 (\%) & BUGLE-96 (\%) & BUGLE-B7 (\%) & ALPAN-VII.0 (\%) \\
\hline${ }^{27} \mathrm{Al}(\mathrm{n}, \alpha)$ & $-5 \%$ & $-5 \%$ & $-2 \%$ & $-1 \%$ \\
\hline${ }^{32} \mathrm{~S}(\mathrm{n}, \mathrm{p})$ & $-5 \%$ & $-5 \%$ & $-2 \%$ & $-2 \%$ \\
\hline${ }^{46} \mathrm{Ti}(\mathrm{n}, \mathrm{p})$ & $-5 \%$ & $-5 \%$ & $-1 \%$ & $-2 \%$ \\
\hline${ }^{54} \mathrm{Fe}(\mathrm{n}, \mathrm{p})$ & $-5 \%$ & $-5 \%$ & $-1 \%$ & $-3 \%$ \\
\hline${ }^{56} \mathrm{Fe}(\mathrm{n}, \mathrm{p})$ & $-5 \%$ & $-5 \%$ & $-1 \%$ & $-1 \%$ \\
\hline${ }^{58} \mathrm{Ni}(\mathrm{n}, \mathrm{p})$ & $-4 \%$ & $-5 \%$ & $-1 \%$ & $-3 \%$ \\
\hline${ }^{63} \mathrm{Cu}(\mathrm{n}, \alpha)$ & $-5 \%$ & $-5 \%$ & $-1 \%$ & $-1 \%$ \\
\hline${ }^{65} \mathrm{Cu}(\mathrm{n}, 2 \mathrm{n})$ & $-90 \%$ & $-90 \%$ & $-90 \%$ & $-90 \%$ \\
\hline${ }^{115} \mathrm{In}\left(\mathrm{n}, \mathrm{n}^{\prime}\right)$ & $-3 \%$ & $-3 \%$ & $-1 \%$ & $-2 \%$ \\
\hline${ }^{237} \mathrm{~Np}(\mathrm{n}, \mathrm{f})$ & $0 \%$ & $0 \%$ & $0 \%$ & $0 \%$ \\
\hline${ }^{238} \mathrm{U}(\mathrm{n}, \mathrm{f})$ & $-3 \%$ & $-3 \%$ & $-1 \%$ & $-3 \%$ \\
\hline
\end{tabular}

Table 8. Percent relative difference in reaction rates with respect to Reference 6 at the cavity capsule.

\begin{tabular}{|c|c|c|c|c|}
\hline Dosimetry Isotope & BUGLE-93 (\%) & BUGLE-96 (\%) & BUGLE-B7 (\%) & ALPAN-VII.0 (\%) \\
\hline${ }^{27} \mathrm{Al}(\mathrm{n}, \alpha)$ & $-2 \%$ & $-2 \%$ & $1 \%$ & $0 \%$ \\
\hline${ }^{32} \mathrm{~S}(\mathrm{n}, \mathrm{p})$ & $-2 \%$ & $-2 \%$ & $2 \%$ & $1 \%$ \\
\hline${ }^{46} \mathrm{Ti}(\mathrm{n}, \mathrm{p})$ & $-3 \%$ & $-3 \%$ & $2 \%$ & $-1 \%$ \\
\hline${ }^{54} \mathrm{Fe}(\mathrm{n}, \mathrm{p})$ & $-2 \%$ & $-2 \%$ & $2 \%$ & $0 \%$ \\
\hline${ }^{56} \mathrm{Fe}(\mathrm{n}, \mathrm{p})$ & $-2 \%$ & $-2 \%$ & $2 \%$ & $0 \%$ \\
\hline${ }^{58} \mathrm{Ni}(\mathrm{n}, \mathrm{p})$ & $-2 \%$ & $-1 \%$ & $3 \%$ & $0 \%$ \\
\hline${ }^{63} \mathrm{Cu}(\mathrm{n}, \alpha)$ & $-2 \%$ & $-2 \%$ & $2 \%$ & $0 \%$ \\
\hline${ }^{65} \mathrm{Cu}(\mathrm{n}, 2 \mathrm{n})$ & $-1 \%$ & $-1 \%$ & $-2 \%$ & $1 \%$ \\
\hline${ }^{15} \mathrm{In}\left(\mathrm{n}, \mathrm{n}^{\prime}\right)$ & $1 \%$ & $5 \%$ & $7 \%$ & $4 \%$ \\
\hline${ }^{237} \mathrm{~Np}(\mathrm{n}, \mathrm{f})$ & $2 \%$ & $10 \%$ & $12 \%$ & $9 \%$ \\
\hline${ }^{238} \mathrm{U}(\mathrm{n}, \mathrm{f})$ & $0 \%$ & $3 \%$ & $5 \%$ & $1 \%$ \\
\hline
\end{tabular}




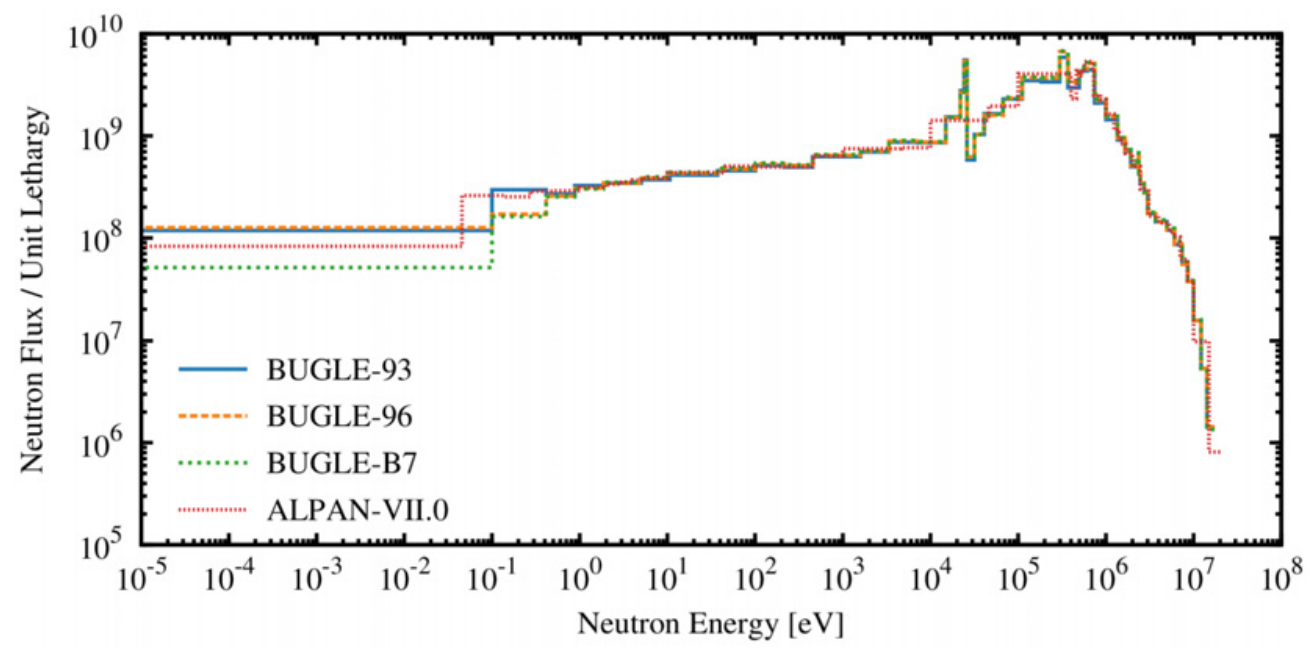

Figure 6. Flux spectrum in the cavity for BUGLE-93, BUGLE-96, BUGLE-B7, and ALPAN-VII.0.

self shielding treatments. ${ }^{65} \mathrm{Cu}(\mathrm{n}, 2 \mathrm{n})$ in the pressure vessel capsule has $90 \%$ relative difference for all libraries with respect to Reference 6. It is anticipated that there is an error in the reaction rate of ${ }^{65} \mathrm{Cu}(\mathrm{n}, 2 \mathrm{n})$ in the pressure vessel capsule listed in Reference 6 . Also, ${ }^{65} \mathrm{Cu}(\mathrm{n}, 2 \mathrm{n})$ in Table 6 with ALPAN-VII.0 has a difference with Reference 6 by $11 \%$ while the other library differences are $2 \%$. The higher difference in ALPAN-VII.0 is thought to be a result of the number of energy groups that cover the ${ }^{65} \mathrm{Cu}(\mathrm{n}, 2 \mathrm{n})$ reaction rate range and will be investigated more in the future. The ${ }^{65} \mathrm{Cu}(\mathrm{n}, 2 \mathrm{n})$ reaction rate is sensitive to very high energy neutrons and has an energy response range of $\mathrm{E}>10.5 \mathrm{MeV}$. ALPANVII.0 has only three groups above $10 \mathrm{MeV}$ and the 47-neutron group structure has four groups above $10 \mathrm{MeV}$. Note that calculational uncertainties for this analysis are provided in Reference 12.

\section{Conclusions}

Flux and reaction rate results of RAPTOR-M3G using BUGLE-93 for the USNRC PWR benchmark with standard core loading verify the transport methodology of RAPTOR-M3G. Libraries developed after BUGLE-93 are generally in good agreement with the BUGLE-93 results for fast neutron sensitive dosimetry reaction rates, with higher differences in ${ }^{237} \mathrm{~Np}(\mathrm{n}, \mathrm{f})$ at the cavity capsule location. While BUGLE-93 can produce similar fluxes for $\mathrm{E}>1.0 \mathrm{MeV}$ and $\mathrm{E}>0.1 \mathrm{MeV}$ and reaction rates at some locations in comparison with the newer libraries, differences can occur depending on the location and calculated parameter of interest.

\section{References}

[1] G. Longoni, S. L. Anderson, World Scientific Publishing Co. Pte. Ltd., 722-732 (2009)

[2] D. T. Ingersoll, J. E. White, R. Q. Wright, H. T. Hunter, C. O. Slater, N. M. Greene, R. E. MacFarlane, R. W. Roussin, ORNL-6795 (1994)

[3] J. E. White, D. T. Ingersoll, R. Q. Wright, H. T. Hunter, C. O. Slater, N. M. Greene, R. E. MacFarlane, R. W. Roussin, ORNL-6795, NUREG/CR-6214, Revision 1 (1999)

[4] J. M. Risner, D. Wiarda, M. E. Dunn, T. M. Miller, D. E. Peplow, B. W. Patton, NUREG/CR-7045, ORNL/TM-2011/12 (2011)

[5] F. A. Alpan, Journal of ASTM International, 548-560 (2012) 


$$
15^{\text {th }} \text { ISRD }
$$

[6] J. F. Carew, K. Hu, A. Aronson, A. Prince, G. Zamonsky, NUREG/CR-6115, BNL-NUREG52395 (2001)

[7] V. McLane and Members of the Cross Section Evaluation Working Group, BNL-NCS-17541, (1996)

[8] M.B. Chadwick, P. Oblozinsky, M. Herman et al, Nuclear Data Sheets, 107, pp. 2931-3060, (2006)

[9] F. A. Alpan, A. Haghighat, Nuclear Science and Engineering, 149, No. 1, pp. 51-64 (2005)

[10] BOT3P Version 5.2: A Pre/Post-Processor System for Transport Analysis, FPN-P9H6-002, ENEA (2007)

[11] SCALE 6.0: "Modular Code System for Performing Criticality and Shielding Analyses for Licensing Evaluation with ORIGEN-ARP," CCC-750 (January 2009) (available from the Radiation Safety Information Computational Center (RSICC), Oak Ridge National Laboratory)

[12] J. D. Andrachek et al, WCAP-14040-A, Rev. 4, Westinghouse Electric Company LLC (2004) 